\title{
Patent Concerns, Unpatentable Procedures
}

\section{Situating Surgical Credit}

In the introduction to his book Surgical Diseases of the Ovaries and Fallopian Tubes, published in 1891, John Bland-Sutton, gynaecological surgeon at the Chelsea Hospital for Women, commented on the publications that abounded in his specialist field: 'the literature relating to surgical diseases of the ovaries displays a notorious amount of egoism', he began, '...nearly every treatise devoted to this subject is mainly a record of personal experience'. ${ }^{1}$ Ovariotomy, over the previous fifty years, had been one of the most enduring topics of discussion among the medical profession. The ethical issues surrounding it had meant there had long been a highly personal dimension to the debate, as practitioners risked their reputations in performing the operation. But by the 1860 s, individual rivalries and disputes were in danger of becoming the defining feature of its practice.

A direct accusation of egoism, such as Bland-Sutton's, was a damning one to be cast at any sector of the medical profession. The drive for reform by practitioners in the middle decades of the nineteenth century had led to the passing of the Medical Act in 1858. Yet, for many, the Act was a disappointment, doing little to actively prevent or regulate the practice of 'quacks', and the lack of desired reform led to a heightened insecurity among doctors over their profession's status. ${ }^{2}$ For those practitioners ostensibly operating within the parameters of orthodoxy,

(C) The Author(s) 2018

S. Frampton, Belly-Rippers, Surgical Innovation and the Ovariotomy

Controversy, Medicine and Biomedical Sciences in Modern History, https://doi.org/10.1007/978-3-319-78934-7_4 
immersing oneself in rhetoric that stressed altruism and the selfless acquisition of knowledge was a fundamental tool in accentuating differences between professional doctors and 'quacks'. These ideals provided a basis upon which the morals and practices of 'orthodox' rivals could be questioned too. Any hint that practitioners might be excessively interested in personal success was subject to intense scrutiny. Doctors inhabited a precarious professional world where accusations of quackery and selfinterest could quickly be rolled out.

Over the mid-part of the century, those who performed ovariotomy gained an unfortunate reputation for this kind of controversy. 'Specialists' of all kinds had begun to attract negative attention in the 1860s, as will be discussed in more detail in the next chapter, and those identifying as specialists in gynaecological diseases were often singled out for their predilection for bickering. An article in The Boston Medical and Surgical Journal in 1881, reporting the news from the London medical world, commented on a meeting of the Royal Medical and Chirurgical Society in which the surgeon for the Samaritan Hospital for Women, John Knowsley Thornton, had argued for the use of antiseptic methods in gynaecological surgery: 'the subject, as usual, afforded the ladies' doctors a grand opportunity for controversy', the anonymous author commented, 'of which, as is their wont, full advantage was taken, and in a manner too, which happily is not usual here amongst the practitioners in other special departments'. ${ }^{3}$ Within the speciality of the diseases of women, the unique distinction that performers of ovariotomy were accorded, as practitioners willing to go into the abdomen, meant that they formed their own professional subset and acquired their own peculiar reputation for controversy. Much of this was increasingly focused on one very particular and contentious issue: the distribution of credit-that is recognition of certain individuals' work-among those who believed themselves responsible for the operation's innovation. That issue is the focus of this chapter.

Historians and sociologists have long been interested in the role of credit and priority in scientific practice. Robert K. Merton in his influential The Sociology of Science (1973) saw awarding credit as central to the construction of norms within professional, scientific culture. For Merton, it was only through credit that originality - that most prized aspect of science-could be validated; thus, 'recognition for originality becomes socially validated testimony that one has successfully lived up to the most 
exacting requirements of one's role as a scientist'. ${ }^{4}$ In recent years, historians of science and technology have shown revitalised interest in the subject, reflecting the growing and high-profile presence of intellectual property in the techno-sciences today. ${ }^{5}$ With this has come a nuancing of ideas about what 'intellectual property' might have meant historically. ${ }^{6}$ Historians of techno-science Christine MacLeod and Gregory Radick have argued that intellectual property can be understood in a narrow sense-for example as it is embodied in legal processes such as patenting-but also broadly, as it is has been expressed in priority and, perhaps more interestingly, 'productivity claims, made when a body of theoretical principles is asserted to underpin useful technologies'. Such work shows historians are finding more fruitful ways of analysing claims of what credit - as we might define the concept, 'intellectual property' being rather presentist-has meant at different times and of which patenting is only one aspect.

In comparison with the history of science, the history of medicine has some way to go in examining the historical antecedents to intellectual property, although recent work suggests interest in the subject is increasing. ${ }^{8}$ Medical practice, understood in the clinical sense, requires disentangling from the broader scope of science. The relative lack of overt engagement that 'orthodox' practitioners had with patenting in the nineteenth century has meant historians have, arguably, glossed over surgeons' anxieties about attaining credit. Histories of patenting and patent medicine, as we shall see, offer a useful contextual framework to the contemporary mores around credit and priority. But they alone do little to elucidate claims to credit in a field like operative surgery, where patenting did not occur. As medical sociologists Judith P. Swazey and Renée C. Fox have shown, however, a multiplicity of different types of credit potentially hover around surgical practice. ${ }^{9}$ What is more, the nature of operative surgery, premised upon methods of physical intervention, has also impacted on how priority and credit have been constituted and rewarded in the field, differentiating it from other areas of medicine.

In this chapter, I consider an overlooked part of ovariotomy's history; that is, how claims to credit were constructed around what was perceived to be new surgical knowledge and practice. I purposely employ the term 'credit' to consider them. This is not only because that was the term frequently used during discussions of priority at the time, but because it also conveys the complex, somewhat obscure, relationship between honour, attribution and financial profit underpinning it. Ovariotomy was 
increasingly symbolic of a bold and novel way of operating. But how was this new knowledge to be owned and credited, if indeed it could be? How was it rewarded or otherwise acknowledged and why was it important that it was? How, if at all, was operative surgery to be understood as the product of intellectual labours? These issues preoccupied surgeons. Significantly, they played out in the wider context of contemporaneous debates on invention, commerce and trade. Unlike technological innovations, such as those occurring in engineering, operations were, for practical and ethical reasons, not deemed patentable. But surgeons lived in a society which increasingly sought to formalise the protection of inventors' ideas in other areas of industry; surgeons were not impervious to this development and it influenced their own internal debates. Credit claims loomed large within the medical press, which not only facilitated numerous priority disputes between medical men but often played an active role as unofficial arbitrator to them. Examining these debates expands not only our understanding of 'intellectual property' as it has been conceptualised in the medical realm, but also the nature of surgeons' professional culture. Issues of priority, patenting and credit were critical to surgeons' self-identity, at a time when their status was in ascendance.

\section{'Attempting to Bind the Winds': The Unpatentability OF SURGERY}

In the middle decades of the nineteenth century, there was increasing recognition in Britain and beyond of the contributions made to society by inventors. It resulted in growing calls for them to be better protected, legally and financially. ${ }^{10}$ Works like Self-Help (1859), the journalist Samuel Smiles' hugely popular paean to self-improvement and endeavour, championed bold pioneers who had innovated in the face of adversity, including those in medicine such as Edward Jenner. ${ }^{11}$ These changes were the manifestation of a growing cult of heroism around invention, much of which centred upon individuals from manufacturing and engineering, people like Isambard Kingdom Brunel, George Stephenson and James Watt, and the highly visible and influential products of their intellectual labours, which had so greatly transformed society. The inventor was no longer the shady eccentric or dishonest swindler but the heroic Briton, contributing to the nation's industrial might. ${ }^{12}$

This changing conception of inventors was most visibly embodied in public support for patenting reform; The Times, an early supporter of the cause, readily invoked the glories of inventors past to argue in 1850 that: 
The rights of inventors can scarcely be spoken of as having a definite existence. It is strange that a Watt, a Hargreave, an Arkwright, should be left to present a humble petition to the crown, imploring that he may for a period of short duration be guaranteed a beneficial interest in his own discovery. ${ }^{13}$

With the Great Exhibition of 1851, an unprecedented platform for new industrial products and processes emerged, enabling for the first time Britons from across the social spectrum to view en masse the fruits of industry from all over the world. But with this platform came concerns over the ease with which inventions on display could be pirated. A hasty intermediate legal measure-the Protection of Inventions Actgave protection to all unpatented British inventions at the exhibition. ${ }^{14}$ More importantly, it reinvigorated and strengthened a lengthy campaign by manufacturers, inventors and other interested parties for wide-scale reform to patent law, principally to increase the short tenure of a year that patents then held and to also reduce the initial price of patents. The Patent Amendment Act, which fulfilled both these criteria, was passed in $1852 .{ }^{15}$

Medical practitioners were for the most part absent from these debates. When patenting was discussed within the pages of the medical journals, it was often with suspicion. For most members of the profession, there was discordance between medicine and the notion of property rights, an inherent contradiction in permitting excessive individual reward within the rhetorical framework of altruism which increasingly bound orthodox medical culture together. As Scottish physician William Gairdner put it in 1868 , in a way which neatly summarised the viewpoint of the profession:

A principle now firmly established in the medical profession...that the status of its members is considered lowered by any attempt to establish property in any remedy, or other invention for the relief of disease; whether by concealment, or by patenting, or otherwise advertising the invention for the benefit of its presumed owner. ${ }^{16}$

In the medical world, the term 'patent' had unseemly connotations that did not reflect the changing place of patents and patentees in other fields of industry. Despite the common parlance used, most 'patent medicines' were trademarked rather than patented because the application for a trademark did not require any disclosure of the components 
of a medicine. Outwardly, patent medicines were treated with disdain by a profession trying hard to rid itself of old associations with useless nostrums and secret remedies. Patent medicines contravened an expectation of openness in practice, and their potential dangers were repeatedly highlighted in the medical press. A Parliamentary Bill in 1884-the Patent Medicines Bill-proposed that all purveyors of patented and trademarked medicines be forced to reveal the ingredients of their remedies, but the Bill was ultimately unsuccessful. ${ }^{17}$ The profession's outward disdain for patent medicines belied a murkier reality; as Lori Loeb has illustrated in her exploration of patent medicines in late nineteenth and early twentieth-century Britain, in private practice, a sizeable number of practitioners prescribed patent medicines or were involved with patent medicine companies as shareholders. ${ }^{18}$

In surgery, the ethical dubiousness of patenting appeared to be writ large. The idea of asserting one's property over an operation was considered untenable from a moral standpoint and unworkable from a practical one. This had been clarified in the 1840s when two American practitioners, Charles T. Jackson and William T.G. Morton, attempted to patent the use of sulphuric ether following their demonstration of the substance's anaesthetic qualities in dental and surgical procedures. ${ }^{19}$ The rapid and widespread uptake of ether among surgeons in 1846 and 1847 in light of the discovery of its astonishing pain-relieving qualities spelled a lucrative opportunity for Jackson and Morton if their claim to property could be enforced. Morton quickly enlisted a patent agent, James A. Dorr, to represent his interests in Britain. Dorr duly wrote to the Lancet and Medical Times to announce that the use of ether inhalation in England and the Colonies was now patented, and that those practitioners who used it would be liable to charges of infringement if they administered it without permission. ${ }^{20}$ Dorr's efforts were resoundingly rebuffed by the profession. Although Morton had initially claimed the compound he used was not ether, but an original composition called 'Letheon', it was widely known that they were one and the same. Thus, the claim to novelty which the patent hinged upon was the use of ether as a method of procuring insensibility in surgical operations rather than the substance itself. To do so, the Medical Times commented, was like 'attempting to bind the winds, not less absurd but improper' ${ }^{21}$ The idea that practitioners would be forced to compensate Morton and Jackson financially each time they provided pain relief in an operation was considered indecent and verging on the ludicrous. It jeopardised the ability 
of surgeons to take on charitable and emergency cases and anyhow, would be almost impossible to enforce, given that it was widely known that the substance was ether, which was readily available. What is more, operations were performed so prolifically, and often privately, it would be impractical to try and track and manage the use of the substance. There was a slipperiness, an intangibility, in establishing ownership in a procedure. Morton tried several times in both America and Britain to enforce his patent but his attempts always failed. The patent was eventually voided. ${ }^{22}$

The intractability of patenting in medicine and especially surgery did not prevent intermittent criticism arising about the lack of reward for the intellectual labours of medical practitioners. Morton's patent agent James A. Dorr himself used his correspondence with the medical press to implore the profession to reconsider their disavowal of patenting, or at the very least, to look at an alternative system which made pecuniary rewards available to doctors. To Dorr's mind, the rank and honour accorded to innovative medical practitioners was hardly a replacement for financial compensation. 'What is honour without the means of subsistence?' Dorr asked. ${ }^{23}$ Twenty-five years later, the physician and journalist Andrew Wynter put forth a similar question in an essay in the influential Whig periodical The Edinburgh Review. Using the successes of anaesthesia and ovariotomy as key examples, Wynter made the case for pecuniary rewards for medical and surgical innovators, arguing that 'some tangible evidence should be given that the nation appreciates the sacrifices daily and hourly made by those who devote their energies and their talents to the promotion of its physical well-being'. ${ }^{24}$ Medical and surgical innovations were, in spirit, the same as any other type of scientific or technological innovation, and yet, when it came to awarding credit, they were treated differently. Surgery most obviously highlighted this disparity; more than other branches of medicine, it aligned with industries like engineering through its manual, practical nature, traversing divisions between medicine and technology. Wynter gloomily compared the situation in Britain to other countries in Europe where 'honours and rewards from the nation await the men who are useful to the country'. ${ }^{25}$ In Britain, medical men were hardly ever officially recognised for their work, Edward Jenner being a rare exception. ${ }^{26}$ In France, on the other hand, there was a long tradition of promoting and rewarding contributions to medicine and surgery with prizes, often in pecuniary form, and by the nineteenth century, both the French Academy of 
Science and French Academy of Medicine offered such rewards. ${ }^{27}$ In 1863, Eugène Koeberlé, at that point one of very few surgeons who performed ovariotomy in France-the operation was still far from established there-was awarded 2000 francs and the prestigious Prix Barbier by the French Academy of Medicine for having performed two successful ovariotomies. ${ }^{28}$ The prize specifically rewarded the invention of instruments, surgical sundries such as new types of bandaging, and operative techniques. ${ }^{29}$

While patents and formal financial rewards were eschewed by the British medical establishment, invention continued to be championed ever more in the medical press. The Lancet's introduction in 1850 of its monthly column 'New Inventions in Aid of the Practice of Medicine and Surgery', for example, responded to doctors' clear interest in new instruments, accessories and devices being fashioned, and gave publicity to the wide range of medical and surgical aides such as siphons, trusses and respirators that were being invented by both doctors and laypeople. The medical press quickly became the main arena through which doctors attempted to claim credit and negotiate priority disputes. In 1837 the Lancet ran an editorial that criticised doctors' excessive interest in credit and priority and their use of journals to assert their property in discoveries and inventions. The journal complained that:

The extent to which this evil has grown can only be fully appreciated by the conductors of the periodical press, or by those who follow with attention the debates of our medical and philosophical societies. Editors' tables are continually laden with letters from gentlemen, who would enforce their claim to 'priority' in some discovery. ${ }^{30}$

By the mid-nineteenth century, medical journals set out significant space for correspondence columns in their pages. The weekly frequency of the Lancet, British Medical Journal, Medical Times and others allowed for speedy claims to credit by doctors; in effect, medical journals became fertile ground for controversies of a personal nature. Despite the Lancet's protestations, the inconsistency in the profession's attitude towards priority claims can be detected. While, ostensibly, the journal proclaimed a disapproval for such disputes, it did not preclude it and other similar titles from publishing and, at times, seemingly encouraging them. Editors and publishers could not have been unaware of the tawdry appeal that personal disputations among doctors would have had among 
its readership. Nor were possible associations with unsavoury self-interest enough to stop practitioners airing their grievances publicly. In the absence of other channels, weekly medical journals, with their reach across both the social spectrum and geographical spread of the professional community, were the most effective tools for initiating claims. As self-declared upholders of professional ethics, journal editors and writers had a degree of authority to act as arbiters in disagreements over priority and credit.

Parallel cultures of ownership in surgery were being constructed. Claims to surgical innovation functioned through periodical correspondence, but also through other interwoven strategies of publishing and eponymy. In the next two sections, I look at two highly public disputes regarding ovariotomy, which, in different ways, attest to the methods surgeons used to attain recognition for their innovations and the difficulties they encountered.

\section{Clay's Adhesion Clam and the Pedicle Dispute}

Ovariotomy formed part of a changing landscape of knowledge management in the middle decades of the nineteenth century. As we have seen, between the 1830s and early 1860s, while controversy over ovariotomy's justifiability raged, there were still only a relatively small number of surgeons performing it, or at least admitting to performing it. As a consequence, discussion centred upon the lengthy narratives of those few men such as Frederic Bird, Charles Clay and Benjamin Phillips who spoke out publicly about their experiences with the operation; the intensely personal accounts that John Bland-Sutton would go on to admonish in the 1890s had in fact been actively encouraged earlier in the century, when claiming personal attachment to an operation had less to do with asserting a priority claim and more to do with acknowledging one's accountability when performing risky surgery. Indeed during this time, such was the polarisation of views about ovariotomy that a surgeon was just as likely to seek credit for 'disowning' the operation as he was to 'owning' it - this was evidently a concern for Robert Liston, who in a letter to the surgeon James Miller in 1835, written shortly after his move to London, expressed hopes that it would not be taken 'amiss that I have disclaimed abdominal surgery. I was first to do so'. ${ }^{31}$

Such was the gravity of the operation that personal responsibility was already deeply embedded in every performance of ovariotomy. But it 
was only as mortality rates diminished that surgeons began to more concertedly use their personal experiences of the operation to make public claims about innovations they had originated. It is no coincidence that these began to occur in earnest in the 1860s, at the very time in which the standing of the operation within medical circles improved considerably, making association with it by means of priority and credit desirable rather than risky. At first, these materialised as outwardly minor, highly technical claims, although the seriousness with which they were taken was testament to the growing status of the operation. They also revealed the relative ease with which ovariotomy, ostensibly a single invention, could be deconstructed into the multiple innovations that constituted it: the surgical instruments used, the method of aftercare, the type of incision and so forth: all had the potential to be claimed as innovative in their own right.

One part of the operation around which multiple credit claims emerged was the method of dividing the diseased ovary from its pedicle and the subsequent treatment of the pedicle afterwards. This was a topic of great interest in the 1860s as practitioners experimented with various ways of making the division, including ligatures, clamps and cauterisation. In 1862, the professional community had had its attention drawn to a new instrument that was being used for pedicle division by practitioners in the Midlands. The instrument, known as an 'adhesion clam', had been devised by the Birmingham obstetrician John Clay (who was no relation to Charles Clay). ${ }^{32}$ John Clay had attracted attention two years previously having translated an extensive work by Austrian obstetrician Franz Kiwisch von Rotterau on diseases of the ovaries. ${ }^{33}$ His 'clam' consisted of two blades which carefully secured the tissue for dividing, at the same time forming a small groove through which either a hot or cold cauterising iron could pass, rubbing or burning any remaining adhesions. Clay had originally invented the instrument for complicated cases where the ovarian tumour had formed attachments to other internal organs. ${ }^{34}$ However, as in principle all ovariotomies required a similar process of tissue division, Clay envisioned that the instrument could be used more generally in the practice of ovariotomy. ${ }^{35}$

John Clay's claim to innovation initially seemed secure, and he made the details and design of the instrument accessible by publishing both of them in the Medical Times in 1862. Clay and other surgeons referred to the instrument as 'Clay's adhesion clam', marking out Clay as its inventor. The naming of procedures, instruments, anatomical 
areas and diseases after inventors was integral to the process of claiming credit and was a practice that speedily gained ground in the midnineteenth century, although it was far from unheard of in surgery before then. ${ }^{36}$ Eponymy was a way of maintaining one's place within the annals of surgery as operations evolved and proliferated. If an operation was named for a surgeon, either by himself or by his supporters, and that name was accepted by peers, at least some kind of legacy was secured; for while operations might be subject to technical changes, the surgeon's name was now indelibly fixed to its development. Simpson's operation, Peaslee's operation, Tait's flap-splitting operation and Battey's operation, the latter of which will be discussed in more detail below, all became part of regular surgical taxonomy. Surgical instruments were also often named for the surgeon who had designed them. This led to a symbiotic relationship between surgeons and 'their' instruments: the most popular instruments tended to be those made by high-status surgeons, whose names suggested the trustworthiness of the tool. The popularity of their instruments then went on to further secure the surgeon's name and reputation. Instruments devised by Thomas Spencer Wells and Isaac Baker Brown, for example, proved to be some of the most fashionable in use for ovariotomy, and Wells in particular was able to enhance his visibility and professional standing with the numerous instruments he devised. ${ }^{37}$

John Clay's clam found favour among his fellow practitioners, and it was quickly taken up and then modified by Isaac Baker Brown as part of his routine method for dividing the pedicle. Brown carefully acknowledged that Clay had originated the instrument. But in 1866 the situation became rather more complex. That year Thomas Spencer Wells referred to Clay's priority not only in creating the instrument but also in being the first to employ the two-part method of compressing and cauterising the pedicle that the instrument enabled. ${ }^{38}$ Published in the British Medical Journal, his assertion provoked a speedy and terse response from Isaac Baker Brown, who in the intervening time had claimed credit for developing this method and argued that John Clay had merely suggested the possible use of the instrument for dealing with the pedicle. Brown appealed to the editor of the journal, dispensing of any pretence that this was about anything other than personal credit: 'Sir, it is of little moment to me whether Mr. Spencer Wells chooses to ignore or to adopt a method of securing the pedicle which has been followed by most satisfactory results', he wrote, 'but I cannot allow him so to place the matter before my medical brethren as to lead them to infer that I had 
nothing whatever to do with it except as a successful operator' ${ }^{39}$ It was an interesting choice of words from Brown, suggesting that successful deployment of the instrument was of little compensation compared to the grander prize of originating a new technique. John Clay reluctantly involved himself in the dispute the following week, stating that he had ' $\mathrm{a}$ great objection to discuss personal matters in the public papers' or 'saying anything about "due credit", but nonetheless did claim credit for both the instrument and the method. ${ }^{40}$

As was often the case, the dispute quietly died down not entirely resolved, but such was the importance of the method of managing the pedicle that it remained a frequent focal point for further innovation and high-profile priority claims. ${ }^{41}$ Disagreements like that between Isaac Baker Brown, Thomas Spencer Wells and John Clay may seem at first to be little more than jealous medical men splitting hairs over the minor details of an invention. Indeed, the frequency with which surgeons claimed each alteration to an instrument was ridiculed by the medical press; 'we may say that if these things were expunged from any instrument maker's catalogue, that catalogue would be considerably emaciated' commented the Lancet, on the many instrument modifications that were advertised. ${ }^{42}$ But they should also be read as testament to the significance even relatively minor credit claims could attain in the heated atmosphere of mid-century medicine, where the value of invention was being radically re-conceptualised. Disputes over the technical minutiae of the operation show also how credit was multifaceted. Potentially, it could be awarded for many different components of the operation, in which material inventions, their modifications, as well as operative performance, could all be, in a sense, owned.

\section{Uneasy Pioneers: Thomas Spencer Wells and Charles Clay}

By far the most controversial credit dispute involving ovariotomy was that which occurred between Thomas Spencer Wells and the more wellknown Clay, Manchester obstetrician Charles Clay, in 1865 (Figs. 4.1 and 4.2). Charles Clay had, up until then, generally been considered Britain's most successful ovariotomist. No significant challenge had ever been made to his claim to have performed the first complete ovariotomy in England by major incision in $1842 .{ }^{43}$ Since then, he had performed the operation repeatedly and by 1863 had had 104 cases, seventy-two of which were successful. ${ }^{44} \mathrm{He}$ was well known both in Britain and 


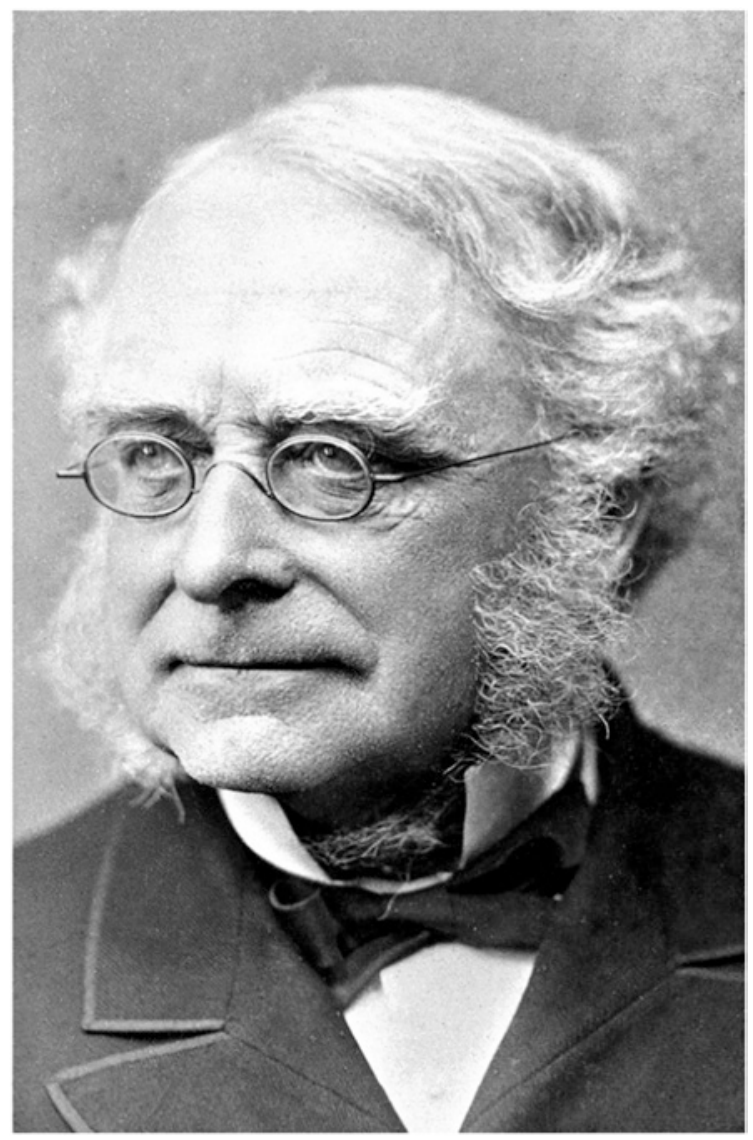

Fig. 4.1 Photograph of Thomas Spencer Wells, taken in the 1880s or early 1890 s by the portrait photographer Herbert Rose Barraud. Wells was firmly ensconced within London's social elite and had received a baronetcy in 1883 (Credit Wellcome Collection CC BY)

abroad and attracted patients from all over the country, although he performed his operations with little fanfare. The son of a corn merchant and Edinburgh educated, up until the 1860s Charles Clay barely ever involved himself in the public debates over the justifiability of the operation, rarely appearing at society meetings and only occasionally 


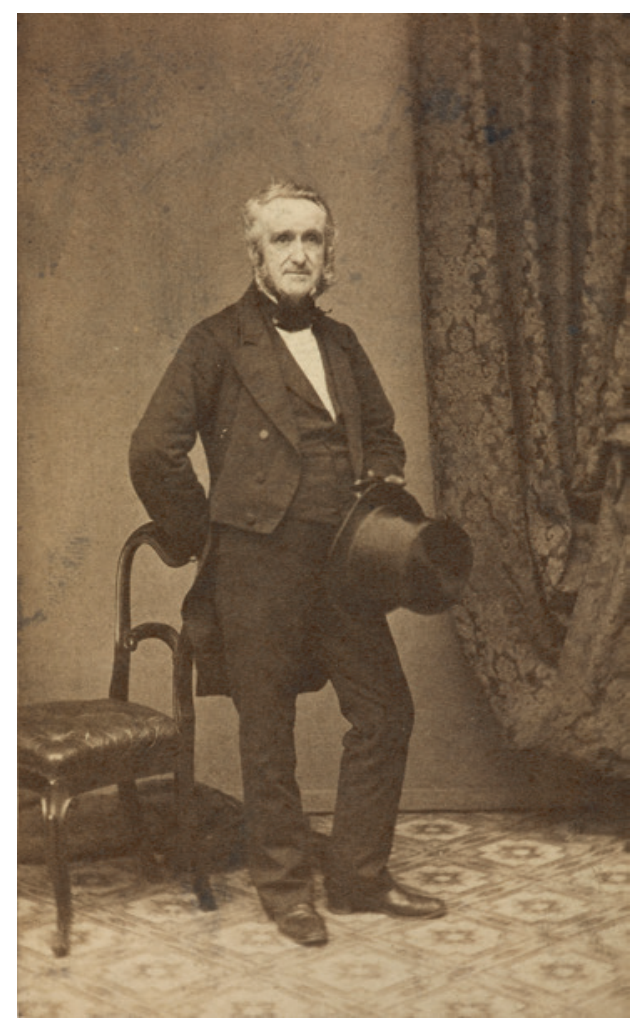

Fig. 4.2 Photograph of Charles Clay. Every inch the Victorian surgeon, the image was probably taken in 1861, by which time he was well established as a practitioner in ovariotomy (Credit The University of Manchester)

publishing on his cases. His only professional teaching appointment had been a brief spell as lecturer of diseases of women and in midwifery at St. Mary's Hospital in Manchester, from which he resigned after a year. ${ }^{45}$ Indeed, he made no bones about his distaste for London medical society, remarking in private correspondence to James Young Simpson that 'the cockneys are a jealous set'. ${ }^{46}$ Clay's publications generally received poor reviews in the predominantly London press, and this likely contributed to his dislike of the capital.

Thomas Spencer Wells, on the other hand, had chosen a very different path. Although he was at pains not to reveal it, he was from a 
relatively humble background. His early career consisted of a long spell in a poorly paid position as an assistant surgeon in the Royal Navy. ${ }^{47}$ Specialism eventually enabled Wells to make a name for himself in London, initially in ophthalmology in the late 1850s, before he secured the role of surgeon at the Samaritan Hospital for Women where his interest in ovariotomy developed. In short, Wells' interest in ovariotomy might be ascribed to calculated professional risks on his part: specialism brought with it the possibility of notoriety. But if practised successfullyespecially in London-it could be a ticket to both eminence and financial riches. Buttressed by his other roles as editor of the Medical Times and Gazette and an active and visible member of London medical society, Wells was by the early 1860s comfortably established in his practice and by the 1880s was one of the most well-respected and well-paid surgeons in London.

As discussed in Chapter 3, it was Wells' publication of Diseases of the Ovaries: their Diagnosis and Treatment in 1865 that sealed the permanence of his reputation. Published in response to the suspicions of opponents that failed cases were being concealed by surgeons, it was not long before the voluminous book was being depicted as a seminal publication that had definitively established ovariotomy as a 'legitimate' operation. In a rather gushing review in the British Medical Journal, Wells' book was readily accorded the accolade of 'the most important addition to the history of ovariotomy, which has yet been published' and was even an 'epoch in the History of Surgery, and is especially creditable to the Surgery of this Metropolis' ${ }^{48}$ Geographical politics was playing out here; a later review appearing in the Edinburgh Medical Journal, while expressing admiration for Wells' work as a 'plain and truth-like record of achievement', was somewhat more cautious and careful to recognise the contributions of non-London-based practitioners like John Lizars and Charles Clay as well as the Edinburgh-based Thomas Keith, who was achieving better results than either Wells or Clay. ${ }^{49}$

The book was undoubtedly influential, but Wells played an active role in encouraging the idea that his monograph was epoch-making. In the book's introduction, he neatly compartmentalised his work into a new category of literature on ovariotomy that differed considerably from that which had come before. While careful to bestow due praise on successful colleagues past and present, it was to himself that he credited the unique position of creator of what he would later term the 'revival' of ovariotomy and by doing so formed a divide 
both in chronology and in technique between his work and what came before. Although not claiming to have originated the operation, he argued that it was he who had rescued it from sliding unpopularity in the 1850s, made it trustworthy and established its re-emergence. This narrative he would continually reaffirm in later speeches, recreating what came before him as a dark phase in the operation's existence and making the new era of ovariotomy his own. Evidently this was a strong enough part of his personal and professional identity that either he or his family wished it to be his lasting legacy-in Brompton Cemetery in London lies Wells' grave, upon which a one-line epitaph is still just about visible: 'He Revived the Operation of Ovariotamy' [sic].

Wells' description of the world that ovariotomists inhabited in the 1850s, if exaggerated, contained a kernel of truth. The disgrace of Frederic Bird lay in stark contrast to Wells' very visible success and meticulous recording of cases. But in one respect his reordering of ovariotomy drew marked attention: his clear attempt to consign Charles Clay to the dubious early history of ovariotomy. Highly successful in his practice, Charles Clay had, in theory, much to his credit. Wells never directly denied Clay's claim to be the first successful ovariotomist in Britain but questioned the impact his work had had on the profession. From Wells' perspective, full credit was denied to Clay because 'his operations not being performed in an hospital before numerous professional witnesses and no connected series of cases being published, his example had but little influence'. ${ }^{50}$ Both assertions-that Clay's claim to the operation was negated by a lack of witnesses and also by a lack of published material-went straight to the heart of contemporary notions of surgical knowledge-making. Surgical operations had, of course, long been public affairs. Surgeons observed the operations of peers as part of the pedagogical transmission of surgical knowledge, something to which Thomas Schlich has applied the Weberian idea of 'tacit knowledge' (of which surgery is arguably a prime example). ${ }^{51}$ But witnessing was also important in terms of verifying claims about operations and could be used either to support or repudiate a surgeon's account of a performance. As Steven Shapin and Simon Schaffer argue in their now seminal work, the establishment of the experimental method in science was in part based on the witnessing of experimental observations by multiple, credible individuals, and it was 
no less the case in surgery. ${ }^{52}$ Despite the often impromptu nature of operations, the necessity of having multiple witnesses was at the very least highly desirable if not rigorously policed, especially for serious or novel operations. This was not lost on Clay who, in a speedily penned and angry response to the publication of Wells' book, published in the Lancet, wrote of his own work:

Every operation has been witnessed generally by three or four professional men; in many instances seven or eight; and in some instances as many as ten or eleven; I believe not less than from six to seven hundred in the whole, and nearly always very different persons from every part of Europe. ${ }^{53}$

Clay's personal notes and correspondence support the idea that this was so. Although filled in somewhat sporadically, Clay noted down numerous medical men who came to witness his operations, including overseas visitors. ${ }^{54}$ But by the middle decades, the literal act of witnessing was not always sufficient in supporting an operation's veracity. Increasingly, it was the type of witness and location of the witnessing that were under scrutiny. The majority of ovariotomies continued to be performed in private dwellings. But hospitals were increasingly regarded as the ideal location for surgical spectacle, especially that which related to new methods and practices. They were places where numerous medical men could conveniently gather, and by doing so, mutually reinforce the authenticity of what was being observed. In 1847, one such spectacular event had taken place at University College Hospital when Robert Liston performed the first British operation to be conducted under ether. Liston 'posted a notice that the operation would take place and the theatre was filled with spectators' ${ }^{55}$ Highly public and bold performances like this projected an image of the surgical community as truthful and open, attributes which were greatly valued. This ideal permitted Wells to be dismissive of Clay's witnesses even though Clay had worked hard to ensure as many people as possible saw his operations. As Clay himself believed, Wells' allegations could only be an allusion to Clay's lack of hospital appointment. Without this role, it was easy for Wells to depict Clay as out of touch with modern practice and out of sight from his peers. With Wells in control of the wards of the Samaritan Hospital in London, but Clay residing in Manchester without any similar situation, Wells was in the stronger position in a surgical culture that was increasingly London-centric. 
The second aspect to Wells' criticism of Clay was the lack of published material about Clay's cases. In a response to Clay's letter, Wells had defended his original criticism, writing:

Half a page of tabulated matter is really all the information published of 50 of Dr. Clay's alleged cases, except some equally useless lists in one of Dr. R Lee's tables. Such meagre unauthenticated reports are absolutely worthless to the scientific inquirer; and, for all purposes of comparison with the results of other operators, Dr. Clay can only be admitted as having operated on 27 patients. ${ }^{56}$

Despite Clay's assertion that he had performed ovariotomy 111 times by 1865, Wells argued that only the twenty-seven operations which had been published could be counted. As we have seen, surgeons were increasingly encouraged to publish on cases to prevent accusations of concealment. But Wells' refusal to adequately credit Clay was indicative of notions once more changing as to the best way of representing surgical experience. Wells argued that cases should be connected together in a monograph form to ascertain credit-just as he had. This idea dismayed Clay; 'surely Mr. Wells cannot mean to infer that to...ensure credit one must publish a book (too often only a polite advertisement of the author's whereabouts?) ${ }^{57}$ queried Clay, who argued instead that the larger circulation and readership of journals brought cases to a wider audience and thus was a more credible means of asserting one's priority and surgical experience. Despite this seemingly logical argument, which factored in the enormous expansion of the medical press over the previous three decades, Clay had failed to acknowledge the value of the monograph in allowing practitioners to coherently bring together multiple cases, which could strengthen their authority in the field.

Clay fought back against the insinuations in Wells' book in a series of letters to the Lancet written between February and April 1865, in which he set out to regain a degree of ownership over the operation. For Wells, credit was intimately tied up with publication and witnessing. Clay, on the other hand, described a concept of credit that was much more closely bound to ideas of originality and priority. That he had performed the first successful ovariotomy was enough to stake his claim in the operation; 'if I had not been the pioneer for this operation in 1842, and for years after that, alone and unsupported', Clay claimed, 'neither 
ovariotomy as an operation, nor Mr. Wells as an ovariotomist, would most probably be heard of at this time' ${ }^{58}$ Clay cultivated a romantic image of himself as the isolated inventor, who had risked his reputation in the name of progress, while the profession had largely turned its back on him.

In a rather contradictory fashion, Clay encouraged readers to see both similarities and differences in his and Wells' operations. In his letters to the Lancet Clay, at times, represented Wells as a poorquality imitator and spoke almost nostalgically about the days gone by when 'I had the operation to myself, when I had rather to originate than imitate plans of operation and after treatment', the insinuation being that Wells has done the latter. ${ }^{59}$ Imitation, as the saying goes, is the highest form of flattery and could be a perfectly acceptable part of surgical practice. Emulating the methods and practices of more senior practitioners was an integral part of learning through 'tacit knowledge' and a sign of respect for one's elders. But imitation had to be acknowledged. Reproduction complicated conceptualisations of authenticity in medicine as it did in other areas of nineteenthcentury industry. If the Great Exhibition marked a genuine Victorian 'moment' in its celebration of novelty and invention, it was also, as Clare Pettitt describes it, a 'moment of crisis in the history of representation', making visible, as it did the potential of new technologies to generate the mass reproduction of everything from newspapers to textiles to sculptures. ${ }^{60}$ As wide-scale manufacturing, publishing and commercialism began their ascent, the effect was to destabilise notions of uniqueness in invention. It generated anxieties about the relative ease with which artistic and literary creations could be replicated, often to a lower quality standard, and appropriated to the detriment of authors' and inventors' intellectual property. The proliferation of ovariotomies similarly made it more difficult to pick out what was original and what was mere imitation.

Clay at other times emphasised the polarity in his and Wells' methods, arguing that their operations were "two distinctly different modes of proceeding, if faithfully carried out', going on to detail the variations in their practice. ${ }^{61}$ Wells, for example, completed ovariotomy by securing a clamp to the remaining pedicle, while Clay used ligatures; Wells championed an incision of about four inches to open the abdomen, while Clay made a larger one, sometimes up to twelve inches. ${ }^{62}$ Clay was especially 
keen on using incision size to differentiate his style of operating from that of his competitors and used it to distinguish himself from both Wells and proponents of the 'minor' operation such as William Jeaffreson, who made incisions of only one or two inches. Both Clay and Jeaffreson insisted they practised entirely different operations from one another, to ensure they both retained a priority claim of sorts. ${ }^{63}$

The disagreement between Clay and Wells rapidly descended into a bitter feud that stretched beyond questions of credit and priority to matters of a more personal nature. Clay accused Wells of performing an operation on a patient with a malignant tumour knowing full well the case was incurable and would almost certainly be fatal. He insinuated that Wells had done so simply to pocket the large fee on offer. This was a step too far for Wells, who promptly took legal action against Clay, which resulted in the latter being forced to make a public apology and to retract his accusation. The Lancet's role in the affair was also scrutinised. The British Medical Journal criticised its long-standing journalistic rival for allowing Clay the space to publicly air his grievance against Wells and in encouraging the personal nature of the disagreement, a charge which stood uncomfortably at odds with the Lancet's professed disapproval of such disputes. ${ }^{64}$

The unfortunate episode between Wells and Clay did not prevent other claims arising; Clay was not the only one sceptical of Wells' depiction of ovariotomy before the 1860s as unworthy of credit. Numerous other attempts were made to draw attention to the work of early practitioners in the field. The significance of reviving older priority claims was most obviously relayed in a letter the Kent physician John Gorham sent to the Lancet in 1874, in which he reminded readers of the role played by the now deceased William West, one of the pioneers of the so-called minor operation. Gorham was keen to highlight West's all but forgotten role in the evolution of ovarian surgery as part of his appeal on behalf West's daughter, whom he described as living in straitened circumstances. Gorham played on the financial successes of present-day practitioners of the operation; 'I believe that some members of the profession are receiving as much as one hundred guineas for a single operation for ovariotomy', Gorham wrote, 'may it not be fair to ask these gentlemen to contribute a trifle to the daughter of one who stood foremost in introducing this operation to the metropolis of London, and so to the whole world?'. ${ }^{65}$ 
Throughout the century, numerous other claims would arise in the medical press from individuals seeking credit for practitioners now deceased and in danger of being forgotten. Most of these claims would fall on deaf ears. ${ }^{66}$

The dispute between Charles Clay and Thomas Spencer Wells continued until the twilight of their careers. In 1880, the public debate between the two erupted again, this time-rather ironically given its previous position-in the pages of the British Medical Journal. When an editorial was published which celebrated Wells' performance of his one thousandth ovariotomy, Clay responded by sending another letter reiterating once more his belief that he was the true originator of ovariotomy in Britain. ${ }^{67}$ Fundamental to Clay's argument this time around was the fact that the term 'ovariotomy' had been coined by James Young Simpson specifically for his operation, intimately linking the procedure with his personal practice. ${ }^{68}$ This was the last time Clay publicly involved himself in the dispute. Ultimately, the controversy strengthened Wells' grip upon the legacy of ovariotomy and for the most part the 'ovariotomy controversy', as it came to be known, did little to dent Wells' eminence. Nonetheless, his rather aggressive dismantling of Clay's legacy did not go unnoticed. In 1884, the Birmingham-based surgeon Robert Lawson Tait, who himself was making a name as a successful performer of ovariotomy, and who was a stern critic of what he saw as the highly elitist world of London surgery, took up Clay's cause. Tait wrote numerous letters condemning Wells' behaviour towards the Manchester surgeon, in one arguing that if it is to be contended that, from the time of McDowell till 1857, there was nothing being done in ovariotomy and that the revival took place in that year at the hands of Spencer Wells, I say it may as well be claimed for him that he revived the moon'. ${ }^{69}$ Tait was a firebrand, always keen to dismantle the reputation of a London surgeon, but he was also astute and highly respected for his surgical work and his words stuck. Wells was accused in at least one other situation-to having been the first to perform a successful ovariotomy in Ireland — of making a false priority claim. ${ }^{70}$ Clay's obituary in the Lancet suggested that Tait's defence of his work gave him some satisfaction. In what could only have been an allusion to Wells, who had been a surgeon to the Royal Household since 1863 and was created a baronet in 1883 , Clay was in the habit of telling friends near the end of his life that 'some men have got baronetcies, some wealth, some positions at Court, but I have got peace of mind'. ${ }^{71}$ 


\section{Imitations and Imports: Ovariotomy on the Global Stage}

The identity and genealogy of ovariotomy were not only understood in terms of individual practitioners. Collectively, British surgeons also sought to establish ovariotomy as a definitively British invention. This was no easy task. Ostensibly, local possession of knowledge was repudiated; as historian of geography David N. Livingstone has argued, 'credible knowledge, we assume, does not bear the marks of the provincial'. ${ }^{72}$ Moreover, by the mid-nineteenth century, the rapid diffusion of new knowledge, technologies and practices across national boundaries appeared to simply be inevitable. The French journalist and critic Edmond About, paraphrased in the popular British periodical The New Monthly Magazine, depicted ovariotomy as one of a number of new inventions that had quickly self-perpetuated and snaked across Europe:

One of the characteristic features of the time we live in is the almost lightning rapidity with which progress develops itself, completes itself, spreads and bears its fruit to the extremity of the globe...in the present day, if a person makes a discovery in science in one country it is simultaneously effected in two or three others. Witness photography, ovariotomy, new planets, chloroform, new metallic bases in the spectrum, and the improvements in the sewing machine. ${ }^{73}$

The inevitability of imitation, and even synchronicity, which seemed to characterise modern society did not preclude resistance to narratives like About's, and on the Britishness of ovariotomy, there was for some, little question. 'Ovariotomy is an operation of British origin, and it is to the labour of British surgeons that its subsequent progress is chiefly due', ${ }^{74}$ proclaimed Thomas Spencer Wells in 1863. Notions of the operation's British identity were consolidated by its diffusion into practice within the British colonies, where it was posited as a civilising influence. A report of the first ovariotomy in New Zealand in 1866 was received rapturously in the British medical press; the operator, Dr. McKinnon, praised for carrying 'far and wide the good deeds and the fame of British Surgery'. ${ }^{75}$

Retaining British identity and authorship of the operation became increasingly important in the 1860s in the face of French surgeons beginning to take up the operation. Having largely rejected ovariotomy in the early part of the century, French surgeons like Auguste Nélaton and Eugène Koeberlé had brought it into practice. It left the British 
with mixed feelings. Some welcomed it, seeing it as additional armour for those fighting to definitively establish the operation as respectable. But it also revealed a possessiveness on the part of the British, not only over ovariotomy but also of a general reputation for surgical authority. In a column in 1864, the Lancet characterised French surgeons as smug and even delusional about their own talents, contending that 'the pretensions of the French school of surgery to a distinct pre-eminence have been maintained by themselves with a self-satisfaction and an apparent confidence which have always been regarded in this country with a secret and placid amusement' ${ }^{76}$

Integral to this viewpoint was the idea that the French were frequently in the habit of imitating British surgical practices without giving their counterparts over the Channel full credit. It was not long before gentle ribbing of the French turned to outright disdain, especially for their delayed uptake of ovariotomy: the British Medical Journal in 1864 described Koeberlé as 'merely a copyist of the English in the matter of ovariotomy'. ${ }^{77}$ The year before, the journal had also poured scorn upon the Prix Barbier and the reward of 2000 francs Koeberlé had received as 'official' recognition for his two successful cases of the operation. The journal scoffed that 'it would be rather an expensive undertaking for the French Academy to reward our successful ovariotomists at the same rate as M. Koeberlé, reminding readers of the greater prolificacy of ovariotomists on the British side of the Channel. By the time Koeberlé wrote the first French language monograph on the operation, L'Ovariotomie, in 1865 , it was regarded as a damp squib by the British journals. The book, aside from the accompanying raw material of the cases, was perceived to draw almost wholly on debates which had already taken place for years in Britain. $^{78}$

The defensiveness of British surgeons was probably unfounded. Most French practitioners were happy to accept their claim to the operation, which they often described as the mode à l'Anglaise, even though the operation had its roots in France. ${ }^{79}$ British doctors' hostility to their French counterparts betrayed wider concerns about the fate of British inventions on the international stage. The prospect of unprecedented competition in science and industry was looming, particularly from France, Germany and America, undermining the country's hitherto unrivalled dominance in industrial development. The Exposition Universelle in Paris in 1867 seemed to crystallise fears of competition and was regarded with suspicion by some British observers, concerned 
that successful inventions ran the risk of being copied by foreign competitors only to be then re-imported back to Britain under the guise of a different nationality. ${ }^{80}$ These concerns infiltrated the surgical profession. That same year, the Birmingham surgeon Sampson Gamgee, who himself would later attain recognition as an important inventor of new surgical sundries, set off on a two-week holiday to Paris which took in the Exposition and was a chance for him to observe the state of surgery in the city. ${ }^{81} \mathrm{He}$ reported his findings to the Lancet: 'many are crowding to Paris, and wondering at the progress made by the French nation in a variety of manufacturing and industrial departments, in which not many years ago, we enjoyed a clear, and scarcely questioned supremacy' ${ }^{82}$ His investigation of French surgery was likewise infused with the language of comparison as he negotiated his way through similar and contrasting aspects of French and British surgery. Gamgee depicted French surgeons as better organised and educated-indeed perhaps too well-educated-at the cost of their technical abilities. British surgeons, on the other hand, he viewed as practically minded doers, who, consequently, were more fearless as operators. Gamgee stretched out this analogy to British industry as a whole:

The engine-driver on a French railway is often a good pupil of the École des Arts et Métiers, knows a great deal about physics, and every now and then is nearly as good a mathematician as he is a mechanic; but he would be sorely puzzled to match one of our men in piloting the Holyhead mail at fifty miles an hour through a November fog. ${ }^{83}$

It was these uniquely British characteristics of courage, practicality, persistence and boldness that for Gamgee defined both British surgeons and engineers and enabled them to retain their standing even in the face of national competition. And yet, while it became increasingly acceptable for engineers to patent their inventions, relatively free of accusations of impropriety, surgeons were bereft of official channels through which to make similar claims.

The relationship between British and American surgeons was of a rather different nature. The kinship British surgeons felt towards their American counterparts was strong and based on an assumption of shared surgical style; 'the bent of the mind of the American surgeon is, like ours, practical rather than scientific', reflected the University College Hospital surgeon John Erichsen after a trip to America in $1874 .{ }^{84}$ While there were 
a small number of surgeons practising ovariotomy in America in the middle decades, in general American societies and journals were content to let the British lead on the topic; most articles on ovariotomy published in the American medical press simply recounted discussions of the operation's justifiability from the other side of the Atlantic. ${ }^{85}$ John Burnham has argued that it was not really until the latter part of the century that American practitioners began to forge their own sense of professional culture distinct from British medicine. ${ }^{86}$ But as American surgeons began to find their voice, some expressed concern about the lack of contribution their country had made to ovariotomy's development, lamenting that British surgeons had been quicker to accept the operation than their American counterparts. ${ }^{87}$ America had been able to maintain its claim to the 'first' ovariotomy, in the form of Ephraim McDowell's operation, but its surgeons were perceived to have not built upon this with further innovation in the field. Moreover, McDowell's contribution was easily slotted into the operation's 'British' identity, because McDowell had been educated in Edinburgh, allowing the operation to still be conceived of as borne of British medical education. ${ }^{88}$

For British surgeons, what happened in America regarding the operation initially made little impact on their own discussions. But in the 1870s things started to change. The work of James Marion Sims had put American gynaecology on the map. Sims was a well-known figure on both sides of the Atlantic, having spent periods working in London and Paris performing his operation for vesico-vaginal fistula, a condition often brought on by childbirth, where a tract formed between the vagina and bladder, usually leading to urinary incontinence. Sims has become notorious in the history of medicine and beyond. In recent years, scholars have called attention anew to Sims' use of enslaved women in his formulation of new surgical operations. Sims' early procedures for fistula were exclusively practised on a small group of captive women; at least three of them, Anarcha, Betsey and Lucy, were subject to multiple surgeries by Sims; Anarcha was operated upon at least thirty times. ${ }^{89}$ Sims operated on the women without an anaesthetic agent, despite its coming into use around the time he began performing the operation, based on a common assumption that black people did not feel pain to the extent that white people did. His protestation that he was merely alleviating their upsetting condition on behalf of their benevolent owners belies a darker reality. ${ }^{90}$ As Deleso Alford Washington has argued, the treatment the women faced " othered" their skin based upon a construction of "race," yet 
"samed" their bodies for purposes of extracting reproductive knowledge, surgical inventions, and innovation to benefit all women'. ${ }^{91}$

It is perhaps not surprising then that it was Sims who at the end of 1877 introduced to Britain another procedure that was to become notorious, 'Battey's operation', named after its claimed originator, the surgeon Robert Battey. Born in 1828 in Georgia and trained in Philadelphia, Battey returned from his duties as a Confederate Army surgeon in 1865, settling into practice in Rome, Georgia. He began to perform ovariotomy in 1869 , his interest in the operation having been piqued in the late 1850s when a tour of Europe had led him to meet many practitioners of the operation, including Thomas Spencer Wells. Battey had begun to hypothesise the use of ovarian surgery for conditions other than tumours soon after his return to practice. Perturbed by the numerous physical and psychological problems suffered by his patients with menstrual irregularities, Battey ascribed to the ovular theory: that ovulation was directly connected to menstruation. He theorised that if both ovaries were removed, menopause would ensue, thus effecting a cure. He put theory into practice in 1872 when he removed both ovaries from his thirty-year-old patient Julia Olmberg, who was suffering from a range of gastric, rectal and epileptic symptoms. Battey and others following in his footsteps would go on to perform the operation for a wide range of conditions, including, most controversially, upon women whose menstrual disorders were believed to be causing mental afflictions such as hysteria and nymphomania. The indications for the operation appeared strikingly vague and led to immediate scepticism about the pathological basis of the operation. ${ }^{92}$ It was an unseemly cross-pollination of alienism and surgery, of the type that had recently laid waste to the career of the ovariotomist Isaac Baker Brown. Brown had become embroiled in one of nineteenth-century London's greatest medical scandals when, in the late 1860s, he began to perform clitoridectomies (the removal of the clitoris) to treat hysteria, epilepsy and a range of other ailments in women. The operations were performed at his specialist institution, the London Surgical Home, without the clear consent of his patients and, in the opinion of many London medical men, with little sound physiological reasoning; Brown was subsequently expelled from the Obstetrical Society. ${ }^{93}$ Operations which traversed into the mental sciences tended to be treated with a degree of suspicion.

In the beginning, Battey referred to the operation as 'normal ovariotomy', a reference to his belief that 'normal' ovaries, without any obvious signs of disease, were the cause of maladies elsewhere in the body. 
He had chosen it also because he believed his method to be a 'truer' ovariotomy than that which was usually performed, which he described as 'irregular ovariotomy', because it involved grossly diseased ovaries. As he rather audaciously described it, 'it was $I$ who had really and truly done an ovariotomy rather than Dr. Ephraim McDowell, as I understand the rule, or law, or principle, which governs medical nomenclature in such cases', assigning himself credit for his purportedly new operation. ${ }^{94}$ Battey's peers were critical of his use of the word 'ovariotomy'. The inference that perfectly normal ovaries were being removed was likely to raise eyebrows and was far from ideal given that the propriety of ovariotomy had so often been questioned already. It was partly for this reason that the operation was renamed by Battey and Sims in the late 1870s. But it was also a convenient opportunity to try and rebrand the operation. In 1877, Sims urged European surgeons to 'unite with us in America in giving it the name of the man who originated the operation'. ${ }^{95}$ The renaming served a number of functions. First, it formed a connection between Battey and the procedure. In what was a calculated risk, Battey's professional reputation was now intertwined with the fate of the operation. Second, it was used to more firmly differentiate the procedure from ovariotomy, expunging the confusion that 'normal' ovariotomy had brought. But most importantly, it was meant to signal the distinctly American nature of the operation, a way of reintroducing American ingenuity back into the ovariotomy narrative. Battey and Sims were moderately successful in their endeavour. The American identity of Battey's operation was generally accepted by British practitioners and filtered into patients' perceptions too. Writing in the British Medical Journal in 1879, the obstetrician Alexander Russell Simpson recounted a patient with chronic menstrual pain who had implored Russell to perform Battey's operation upon her after he had mentioned the developments occurring in American surgery. According to Russell, the patient claimed to have been 'reading all about' the new operation, asking Russell 'can't you do here what the doctors in America can do?'.96 However, the renaming of the operation did not catch on entirely. In 1872, the American surgeon Edmund Peaslee had drawn attention to the failure of 'ovariotomy' as an explanatory term and had suggested 'oöphorectomy' as a more accurate description (the suffix '-ectomy' denoting removal, whereas 'otomy' implied only incision). British practitioners began to use the latter term interchangeably with 'Battey's operation' to describe procedures that involved the removal of both ovaries to treat conditions other than ovarian tumours. And by the late 1880 s, it was 
'oöphorectomy' that was more commonly used to describe the procedure Battey claimed as his own. The complex nomenclature around ovarian surgery will be discussed in more detail in Chapter 6 .

The uniqueness of Battey's operation was also contested across the international stage. Recalling Edmond About's pronouncement of the rapid and widespread diffusion of modern innovations, it quickly became apparent that German gynaecologist Alfred Hegar had begun performing similar operations to Battey at around the same time. ${ }^{97}$ In Britain, Robert Lawson Tait also had his own procedure, 'Tait's operation', involving the removal of the ovaries and Fallopian tubes to cure inflammatory disease. Tait always denied using ovarian surgery to treat mental afflictions, but his operation was similar enough to Battey's that he repeatedly felt the need to emphasise their difference: 'what Dr. Battey has advocated and practised, I, for one, practically have never performed' he wrote to the British Medical Journal. ${ }^{98}$

Battey's operation received mixed reviews from the British medical press. The revelation that it was being used experimentally to treat forms of insanity startled many, even those who were themselves ovariotomists. Thomas Spencer Wells spoke out forcibly against the new operation. In an essay published in the American Journal of the Medical Sciences in 1886, and later reprinted as a pamphlet, he described the procedure as an 'unnecessary mutilation of young women'. ${ }^{99}$ For Wells, this unwelcome development could only be understood through the framework of nationality, its roots in the 'fanaticism' of American surgeons. ${ }^{100}$ But, he warned, its implications were global; 'the danger is now increasing as the operation is becoming world-wide' Wells wrote, 'the oöphorectomists of civilization touch hands with the aboriginal spayers of New Zealand'. ${ }^{101}$ Wells picked his words carefully, crafting an image of oöphorectomy that suggested savagery, in stark contrast to ovariotomy, which he depicted as a model of colonial advance, likening it to 'the discovery of the Californian diggings or the African diamond mines'. ${ }^{102}$ Wells entitled the essay 'On the Castration of Women', provocatively ignoring the more respectable nomenclature, to use instead a word which carried stigma and which suggested a violent, animalistic procedure rather than a progressive one. Battey's operation was never able to achieve full acceptance in Britain. Battey had gambled his name in the hope that personal association with his innovation would bring fame and prestige. Instead, it has brought enduring notoriety.

Was the nationality of an operation determined by its country of origin or the country where it had been most successful? Through what 
ways could a country make a claim of ownership to an operation? And why was there a need to do so? Broadly speaking, ovariotomy was identified as a British innovation; British practitioners succeeded in making it so through consistently espousing their contributions, but perhaps more so by calling into question the contributions of other countries. Defensive and possessive in equal parts, British surgeons were suspicious of the alleged imitations of the French and the deviations of the Americans, both of which potentially threatened the carefully cultivated identity of ovariotomy within Britain. On the international stage, retaining the Britishness of the operation was essential in the face of growing professional and industrial competition from other nations.

\section{Conclusion}

This chapter has tried to make explicit how surgeons managed and claimed the vast proliferation of knowledge that was being generated around ovariotomy. At first glance, there may seem little to connect the operation with notions of intellectual property beyond the personal disputes that doctors were notorious for. After all, medicine and surgery played a lesser role within wider societal debates on patenting and credit occurring at the time, and no patenting existed in relation to the operation. Yet on closer inspection, the apportioning of the knowledge and practice that constituted 'ovariotomy' reveals cultural and political concerns. The chronology of these disputes also signals the ostensible establishment of the operation; it was only in the 1860s as ovariotomy came to be viewed as justifiable by most of the profession that credit claims around it proliferated. In an atmosphere of heightened awareness about the role of the inventor in society, ovariotomists found methods for crediting those who innovated in the field. Being the first to perform an operation-even being the first to consistently perform an operation-did not necessarily secure one's legacy. Nor was credit an inevitable consequence of innovation. Rather, to ensure credit one had to maintain it, remaining visible through publishing, inviting high-profile practitioners to witness operations, inventing instruments and using eponyms. The ability to maintain a claim was also as much to do with a surgeon's social status and location, as Charles Clay would have been only too painfully aware.

Settling priority disputes was not only about personal reputations. It brought order to the operation and it allowed surgeons to reshape the narrative of ovariotomy, imbuing it with a desired sense of teleology, a national identity and its own assemblage of heroes. The need for 
definition and classification was fundamental to bringing respectability to the operation-both while it was being established and later in the century when new forms of ovarian surgery began to flourish. To do so was no mean feat. Debates over the nuances of the operation highlighted that the procedure was the sum of multiple innovations; the size of the incision made, the method of treating the pedicle, the type of instrument used-all could potentially hold value to those who had originated them. Moreover, it was not always easy to reconcile individual practices of the operation with a concrete definition of ovariotomy; operations tended to be highly individualistic, moulded by the idiosyncrasies of the operator and patient. In ovariotomy especially, where there was so often disagreement about what the best mode of performance was, the operation's identity was malleable.

Intellectual property in medical practice has generally been integrated into broader narratives of science and technology, but knowledge production in surgery frequently defied 'scientific' organisation and management. The idea of surgery as both an art and a science was evoked as a positive characteristic of the profession, yet the dual components existed in tension with one another. 'People...forget that operative surgery is an art', wrote the surgeon and lithotomist Sir Henry Thompson to Ernest Hart, editor of the British Medical Journal in 1886, 'the personality of the artist should be largely taken into account'. ${ }^{103}$ Practitioners of ovariotomy wished desperately to have their personal contributions to the field recognised, but always present was a fine line between attaining sufficient credit and potential accusations of egoism. Social credit-with the hope of future financial reward-was hard won but easily lost by surgeons. The process of securing credit could be lengthy, delayed and complex or even fail completely. Nonetheless, if one was successful, the rewards could be bountiful; these accolades made the risks of innovation worthwhile.

\section{Notes}

1. John Bland-Sutton, Surgical Diseases of the Ovaries and Fallopian Tubes (Philadelphia: Lea Bros, 1891), v.

2. M.W. Weatherall, 'Making Medicine Scientific: Empiricism, Rationality, and Quackery in Mid-Victorian Britain', Social History of Medicine 9, no. 2 (1996): 175-194. More recent scholarship has emphasised that the 1858 Act was a process of negotiation between MPs and medical 
men, in which the former limited the powers of the act for the sake of patient choice. See M.J.D. Roberts, 'The Politics of Professionalization: MPs, Medical Men, and the 1858 Medical Act', Medical History 52, no. l (2009): 37-56.

3. Anonymous, 'Letter from London', The Boston Medical and Surgical Journal 104, no. 6 (10 February 1881):142-143.

4. Robert K. Merton, The Sociology of Science (Chicago: Chicago University Press, 1973), 293.

5. To take one example, the increasing pervasiveness of 'technology transfer' in the UK, that is, the securing of intellectual property for scientific research at educational institutes, and its subsequent commercial exploitation.

6. The term 'intellectual property' did not emerge as part of regular legal vernacular until the end of the nineteenth century. However, it can be used to broadly desrcibe the range of issues surrounding the ownership of intellectual labours, from patenting to trade marking, to non-legal methods of managing and recognising credit such as publication, peer recognition and pecuniary reward.

7. Christine Macleod and Gregory Radick, 'Claiming Ownership in the Technosciences: Patents, Priority and Productivity', Studies in History and Philosophy of Science Part A 44, no. 2 (2013): 181.

8. See, for example, James F. Stark, 'Introduction: Plurality in Patenting: Medical Technology and Cultures of Protection', British Journal of the History of Science 49, no. 4 (2016): 533-540.

9. Judith P. Swazey and Renée C. Fox, 'The Clinical Moratorium', in Essays in Medical Sociology: Journeys into the Field, ed. Renée C. Fox (New York: Transaction Publishers, 1988), 337 incl. n. 32.

10. Christine MacLeod, Heroes of Invention: Technology, Liberalism and British Identity: 1750-1914 (Cambridge: Cambridge University Press, 2007), 2-3.

11. Samuel Smiles, Self-Help: With Illustrations of Conduct and Perseverance (Rockville: Serenity, 2008). Smiles cites Edward Jenner (1747-1823) as an example, 102-103.

12. MacLeod, Heroes of Invention, 33-34. This reputation came in part from the fact that, in the early modern period, patentees were often favourites of the Royal Court who had been issued monopolising patents that ruined other 'honest' tradesmen, and who often charged the public extortionate prices.

13. Anonymous, 'Editorial', The Times 20665 (6 December 1850), 4.

14. Clare Pettitt, Patent Inventions: Intellectual Property and the Victorian Novel (Oxford and New York: Oxford University Press, 2004), 123-124. 
15. There were numerous attempts earlier in the century to reform the patenting system, and minor changes were made with the Patent Act of 1835, which allowed the extension of some patents. But overall the Act made relatively little difference. For an overview, see H.I. Dutton, The Patent System and Inventive Activity During the Industrial Revolution, 1750-1852 (Manchester: Manchester University Press, 1984), 34-56.

16. Anonymous, 'The Theory of Professional Remuneration', British Medical Journal 1, no. 371 (8 February 1868): 122.

17. House of Commons Debate, Hansard 286 ser.3 (26 March 1884), 801-811, http://hansard.millbanksystems.com/sittings/1884/mar/26, accessed 8 August 2013. The Bill never made it to a second reading, most likely because the profession's disdain for the industry in patent medicines did not reflect the opinion of the public, who had an increasing appetite for such products throughout the second half of the century; additionally, the continued revenue patent medicines generated was probably enough to dissuade parliament from their regulation. See T.A.B. Corley, 'Interactions Between the British and American Patent Medicine Industries, 1708-1914' (pamphlet reprint from Business and Economic History, Series 2, 16, 1987), 112.

18. Lori Loeb, 'Doctors and Patent Medicine in Modern Britain: Professionalism and Consumerism', Albion: A Quarterly Journal of British Studies 33, no. 3 (2001): 416-418. For more on 'orthodox' practitioners' financial and professional interests in patented devices, see Takahiro Ueyama, Health in the Marketplace: Professionalism, Therapeutic Desires, and Medical Commodification in Late-Victorian London (Palo Alto: The Society for the Promotion of Science and Scholarship, 2010).

19. Sally Frampton, "Honour and Subsistence": Invention, Credit and Surgery in the Nineteenth Century', British Journal of the History of Science 49, no. 4 (2016): 562 .

20. Frampton, 'Honour and Subsistence', 566.

21. 'To Correspondents', Medical Times 15, no. 381 (16 January 1847): 307.

22. S. S. Fisher, Reports of Cases Arising Upon Letters Patent for Inventions Determined in the Circuit Courts of the United States, vol. 2 (Cincinnati: Robert Clarke \& Co., 1871), 320-330.

23. J.A. Dorr, 'Are Improvements in Medicine and Surgery Proper Subjects of Patents?' Lancet 49, no. 1237 (15 May 1847): 524.

24. Andrew Wynter, 'Review Essay', Edinburgh Review, or Critical Journal 136, no. 278 (1872): 515.

25. Wynter, 'Review Essay', 514.

26. Edward Jenner received $£ 30,000$ from Parliament for his pioneering work on vaccination. Anonymous, 'The Theory of Professional Remuneration', (8 February 1868): 122. 
27. George Weisz, The Medical Mandarins: The French Academy of Medicine in the Nineteenth and Early Twentieth Centuries (Oxford: Oxford University Press, 1995), 98-103.

28. L.F. Hollender, 'Eugène Koeberlé (1828-1915): Père de la Chirurgie Moderne', Annales de Chirurgie 126, no. 6 (2001): 574.

29. Anon. 'Le Prix Barbier ses Métamorphoses', Revue de Thérapentique Medico-Chirurgicale 2, no. 21 (1861): 562.

30. 'Editorial', Lancet 28, no. 726 (29 July 1837): 670.

31. Letter from Robert Liston to James Miller (26 May 1835) MS6085 (Wellcome Collection).

32. Even though John Clay was no relation to Charles Clay, their similar names were a cause for confusion. In fact, John Clay first publicly addressed the issue of the clam's priority because of a lecture Brown had given describing the instrument as originated by a 'Dr. Clay', leading John Clay to raise concerns that this would suggest the instrument had been created by Charles Clay. John Clay, 'Ovariotomy: Clay's Adhesion Clam', British Medical Journal 1, no. 225 (22 April 1865): 418-419.

33. John Clay, Chapters on Diseases of the Ovaries Translated, by Permission, from Kiwisch's Clinical Lectures (London: Churchill, 1860).

34. Diseased ovaries were commonly found to be adhering to other organs and tissues such as the liver, stomach and omentum.

35. John Clay, 'Adhesion Clam; A New Instrument for Aiding the Removal of Ovarian Tumours etc', Medical Times and Gazette 1 (21 June 1862): 640-641.

36. In 1720 , for example, the surgeon John Douglas claimed to have introduced the supra-pubic lithotomy (or 'high' operation) into British surgical practice in a pamphlet that was rather proprietarily entitled Lithotomia Douglassiana (London: Thomas Woodward, 1720).

37. 'Wells' artery forceps, originally used to prevent bleeding in ovariotomy cases, remain a staple of the operating theatre even today.

38. Thomas Spencer Wells, 'Clinical Remarks on Different Modes of Dealing with the Pedicle in Ovariotomy', British Medical Journal 2, no. 301 (6 October 1866): 378.

39. Isaac Baker Brown, 'Management of the Pedicle in Ovariotomy', British Medical Journal 2, no. 302 (13 October 1866): 421.

40. John Clay, 'On Management of the Pedicle in Ovariotomy', British Medical Journal 2, no. 303 (20 October 1866): 449.

41. This included American surgeon James Marion Sims as well as the Birmingham-based surgeon Robert Lawson Tait. Sims pioneered the use of silver wire ligatures for those ovariotomists who preferred to secure the pedicle stump within the peritoneal cavity, while Lawson Tait in the 1890s further innovated on Brown and Clay's inventions by 
introducing a cautery-clamp which ran an electric current through the cautery, sufficiently ensuring the pedicle was 'cooked' and thus reducing the chance of haemorrhage. See James Marion Sims, 'Ovariotomy: Pedicle Secured by Silver-Wire Ligatures: Cure', British Medical Journal 1, no. 432 (10 April 1869): 326; Robert Lawson Tait, 'The Evolution of the Surgical Treatment of the Broad Ligament Pedicle', Lancet 147, no. 3794 (16 May 1896): 1338-1841.

42. 'Reviews and Notices of Books: The Story of My Life by J. Marion Sims', Lancet 126, no. 3232 (8 August 1885): 247.

43. Some ascribed the first successful ovariotomy in Britain to John Lizars who, as we have seen, had successfully removed a diseased ovary in 1825 but probably not cured the patient, whose other ovary was also diseased. Clay acknowledged Lizars and credited himself only as the first to have performed ovariotomy in England. See Charles Clay, 'Dr. Clay's Reply to Dr. Granville on Ovarian Extirpation', Medical Times 8, no. 204 (19 August 1843): 327.

44. 'Obstetrical Society of London: Wednesday March 4', Lancet 81, no. 2067 (11 April 1863): 417. This appears to have been a rare visit made by Charles Clay to the Obstetrical Society of London.

45. Peter D. Mohr, 'Clay, Charles (1801-1893)', in Oxford Dictionary of National Biography (Oxford University Press, September 2004); online edn, October 2006, http://www.oxforddnb.com/view/article/5558, accessed 4 May 2010. Mohr suggests this was due to 'the pressure from his private practice'.

46. Letter from Charles Clay to James Young Simpson (March 25 c. 1848) GB 779 RCSEd JYS/37 (Royal College of Surgeons of Edinburgh).

47. Jane Eliot Sewell, 'Wells, Sir Thomas Spencer, First Baronet (18181897)', in Oxford Dictionary of National Biography (Oxford University Press, 2004); online edn, October 2008, http://www.oxforddnb.com/ view/article/29018, accessed 9 August 2013.

48. 'Review: Diseases of the Ovaries: their Diagnosis and Treatment', British Medical Journal 1, no. 214 (4 February 1865): 117.

49. 'Review: Diseases of the Ovaries: their Diagnosis and Treatment', Edinburgh Medical Journal 13, no. 1 (1867): 565-566.

50. Thomas Spencer Wells, Diseases of the Ovaries: their Diagnosis and Treatment, vol. 1 (London: John Churchill \& Sons, 1865), x.

51. Thomas Schlich, Surgery, Science and Industry: A Revolution in Fracture Care, 1950s-1990s (Basingstoke: Palgrave Macmillan, 2002), 65.

52. Steven Shapin and Simon Schaffer, Leviathan and the Air-Pump: Hobbes, Boyle, and the Experimental Life (Princeton: Princeton University Press, 2011), 56-60.

53. Charles Clay, 'On Ovariotomy and Ovariotomists', Lancet 85, no. 2165 (25 February 1865): 201. 
54. Charles Clay's case book, M/C Medical Collection-cat.9.11.54 MNB (Manchester Medical Collection, University of Manchester). Furthermore, Clay's remaining archives indicate that at least one prominent foreign medical man-the American physician and later inventor William Francis Channing-visited Clay to observe his work; letter from William Channing to Charles Clay (14 August 1855) no class mark (Manchester Medical Collection, University of Manchester).

55. D'Arcy Power, 'Liston, Robert (1794-1847)', rev. Jean Loudon, Oxford Dictionary of National Biography (Oxford University Press, 2004), http:// www.oxforddnb.com/view/article/16772, accessed 29 July 2013.

56. Spencer Wells, 'Results of Ovariotomy', Lancet 85, no. 2167 (11 March 1865): 272.

57. Clay, 'On Ovariotomy and Ovariotomists' (25 February 1865): 201.

58. Clay, 'On Ovariotomy and Ovariotomists' (25 February 1865): 201.

59. Charles Clay, 'The Ovariotomy Controversy', Lancet 85, no. 2171 (8 April 1865): 380.

60. Pettitt, Patent Inventions, 85.

61. Charles Clay, 'On Ovariotomy and Ovariotomists', Lancet 85, no. 2166 (4 March 1865): 227.

62. Charles Clay, 'On Ovariotomy and Ovariotomists' (4 March 1865): 227.

63. The division between the two styles was certainly encouraged by Jeaffreson who, in the wake of others beginning to practise the 'major' operation, described himself in a letter in 1843 to the Lancet as 'the originator of the minor operation'. William Jeaffreson, 'Mr Jeaffreson's Operation for Ovarian Dropsy', Lancet 41, no. 1055 (18 November 1843): 217.

64. 'Freedom V License', British Medical Journal 2, no. 259 (16 December 1865): 637-638.

65. John Gorham, 'On the Revival of Ovariotomy', Lancet 103, no. 2639 (28 March 1874): 441.

66. In the 1870s, there was an attempt to resurrect the name of Frederic Bird, the memories of whose earlier work in the field had been marred by the controversy surrounding his use of exploratory incisions, described in Chapter 3. Samuel Lane's nephew also wrote to the British Medical Journal in 1884 to remind readers that his uncle performed the first successful ovariotomy in London, while the physician Heywood Smith wrote to the Lancet to claim that his father, Protheroe Smith, had performed a successful ovariotomy even before Charles Clay. Jonathan Potter, 'The History of Ovariotomy', British Medical Journal 2, no. 678 (27 December 1873): 770-771; James R. Lane, 'The Revival of Ovariotomy', British Medical Journal 2, no. 1250 (13 December 1884): 1212; Heywood Smith, 'The Early History of Ovariotomy', The Lancet 142, no. 3658 (7 October 1893): 898. 
67. 'Ovariotomy', British Medical Journal 1, no. 1016 (19 June 1880): 931-932.

68. Clay claimed that Simpson had written to him 'my dear Dr. Clay, the operation is your own; none can rob you of your claim. Call it ovariotomy, not peritoneal section'. Charles Clay, 'History of Ovariotomy', British Medical Journal 2, no. 1020 (17 July 1880): 110.

69. Lawson Tait, 'The Revival of Ovariotomy', British Medical Journal 2, no. 1249 (6 December 1884): 1165.

70. 'Dublin', Lancet 82, no. 2098 (14 November 1863): 578-579.

71. 'Obituary: Charles Clay', Lancet 142, no. 3657 (30 September 1893): 846.

72. David N. Livingstone, Putting Science in Its Place: Geographies of Scientific Knowledge (Chicago: The University of Chicago Press, 2003), 1.

73. 'Progress in a French Point of View', New Monthly Magazine 131, no. 523 (1864): 255.

74. Thomas Spencer Wells, 'On the History and Progress of Ovariotomy in Great Britain', Medico-Chirurgical Transactions 46 (1863): 36.

75. 'Ovariotomy in New Zealand', Medical Times and Gazette (16 June 1866): 640 .

76. 'Medical Annotations: A Laurel for English Surgeons', Lancet 79, no. 2001 (4 January 1862): 12.

77. 'The Week', British Medical Journal 2, no. 201 (5 November 1864): 528.

78. 'Reviews and Notices of Books', British Medical Journal 2, no. 239 (29 July 1865): 121.

79. Jean Delaporte, 'Hydropsie Enkistée de l'Ovarie Attaquée Par Incision', Mémoires de l'Académie Royale de Chirurgie 2 (1753): 455.

80. Graeme Gooday, 'Lies, Damned Lies and Declinism: Lyon Playfair, the Paris 1867 Exhibition and the Contested Rhetorics of Scientific Education and Industrial Performance', in The Golden Age: Essays in British Social and Economic History, 1850-1870, ed. Ian Inkster (Aldershot: Ashgate, 2000), 105-120, 116. English patent law would be unable to protect against this.

81. His most famous invention was 'Gamgee tissue', a new type of dry, absorbent surgical dressing which contained cotton wool.

82. Sampson Gamgee, 'The Present State of Surgery in Paris', Lancet 90, no. 2296 (31 August 1867): 273.

83. Sampson Gamgee, 'The Present State of Surgery in Paris', Lancet 90, no. 2313 (28 December 1867): 802.

84. John Erichsen, 'Impressions of American Surgery', Lancet 104, no. 2673 (21 November 1874): 717.

85. Randolph E. Peaslee, Ovarian Tumors: Their Pathology, Diagnosis and Treatment, Especially by Ovariotomy (New York: D. Appleton, 1872), 247. 
In a situation akin to that of Charles Clay, Philadelphia surgeon Washington Atlee was the only surgeon performing the operation with consistency in America during the 1850s and 1860s, but with little publicity of his operations.

86. John Burnham, 'The British Medical Journal in America', in Medical Journals and Medical Knowledge: Historical Essays, ed. William F. Bynum, Stephen Lock, and Roy Porter (London and New York: Routledge, 1992), 166.

87. Peaslee, Ovarian Tumors, 250.

88. However, even McDowell's legacy was threatened. As Jean Bowra has noted, the partial excision of an ovary by Scottish surgeon Robert Houstoun in 1701 was, by the late nineteenth century, being claimed by some British surgeons to have been the first ovariotomy rather than Ephraim McDowell's procedure in 1809. Lawson Tait, in particular, championed this version of ovariotomy's history. Jean Bowra, 'Making a Man a Great Man: Ephraim McDowell, Ovariotomy and History', http://eprints.qut.edu.au/3454/1/3454.pdf (Paper Presented to the Social Change in the 21 st Century Conference, Centre for Social Change Research, Queensland University of Technology, 28 October 2005): 4.

89. Deleso Alford Washington, 'Critical Race Feminist Bioethics: Telling Stories in Law School and Medical School in Pursuit of "Cultural Competency", Albany Law Review 72, no. 4 (2009): 972.

90. James Marion Sims, The Story of My Life (New York: D. Appleton, 1884), 228.

91. Washington, 'Critical Race Feminist Bioethics', 964.

92. Lawrence D. Longo, 'The Rise and Fall of Battey's Operation: A Fashion in Surgery', Bulletin of the History of Medicine 53, no. 2 (1979): 249.

93. 'Obstetrical Society of London', Lancet 89, no. 2275 (1867): 429-441. The Obstetrical Society called a special meeting to consider the fate of Brown and for members to vote as to whether he should be expelled from the organisation. The debate, published in the Lancet, makes for fascinating reading. Society members packed into the crowded hall to hear the case for and against Brown, although his fate was likely sealed before he had even entered the room, for Brown's supporters were few and far between by this point. The surgeon was barely able to speak before jeers broke out. He was expelled with 194 votes for and 38 against.

94. Robert Battey, Normal Ovariotomy (Atlanta: Herald Publishing Company, 1873), 5. As quoted in Longo, 'The Rise and Fall of Battey's Operation', 249.

95. James Marion Sims, 'Remarks on Battey's Operation', British Medical Journal 2, no. 877 (29 December 1877): 918. 
96. Alexander Russell Simpson, 'History of a Case of Double Oophorectomy, or Battey's Operation: With Remarks', British Medical Journal 1, no. 960 (24 May 1879): 763.

97. Alfred Hegar, Robert Battey and Thomas Spencer Wells, 'Castration for Nervous and Mental Diseases: A Symposium', American Journal of Medical Sciences 184 (1886): 455-490.

98. Lawson Tait, 'Removal of the Uterine Appendages', British Medical Journal 2, no. 1125 (22 July 1882): 153. For more on Tait's operation, see Regina Morantz-Sanchez, Conduct Unbecoming A Woman: Medicine on Trial in Turn-of-the-Century Brooklyn (Oxford: Oxford University Press, 1999), 100.

99. Thomas Spencer Wells, Modern Abdominal Surgery: The Bradshaw Lecture Delivered at the Royal College of Surgeons of England. With an Appendix on the Castration of Women (London: J. A. Churchill, 1891), 35.

100. Wells, Modern Abdominal Surgery, 42.

101. Wells, Modern Abdominal Surgery, 43.

102. Wells, Modern Abdominal Surgery, 36.

103. Letter from Sir Henry Thompson to Ernest Hart (29 August 1886) MS 5424/13; emphasis in original (Wellcome Collection).

Open Access This chapter is licensed under the terms of the Creative Commons Attribution 4.0 International License (http://creativecommons.org/licenses/ by $/ 4.0 /$ ), which permits use, sharing, adaptation, distribution and reproduction in any medium or format, as long as you give appropriate credit to the original author(s) and the source, provide a link to the Creative Commons license and indicate if changes were made.

The images or other third party material in this chapter are included in the chapter's Creative Commons license, unless indicated otherwise in a credit line to the material. If material is not included in the chapter's Creative Commons license and your intended use is not permitted by statutory regulation or exceeds the permitted use, you will need to obtain permission directly from the copyright holder.

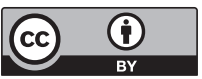

